\title{
INSTITUTIONS AND INVESTMENT EFFICIENCY: AN EMPIRICAL INVESTIGATION
}

\author{
By Nguyen Van Phuc ${ }^{l}$
}

\section{Introduction}

New Institutional Economics has revived the important role of institutions on economic growth. North (1990) was a pioneering work. Institutions are defined as 'the humanly devised constraints that structure human interaction. They are made up of formal constraints (for example, rules, laws, constitutions), informal constraints (for example, norms of behaviour, conventions, self-imposed codes of conduct), and their enforcement characteristics' (North 1994, p. 360). Formal institutions are constraints sanctioned by state power if individuals violate them, while informal institutions are self-imposing constraints. According to North, of primary importance to economic performance is the economic institutions that determine transaction costs and influence the incentive structure in society such as the structure of property rights and the presence and perfection of markets.

There are now various empirical studies on the effect of institutions on economic growth. Most studies used crosscountry regressions to determine the effect of institutional quality on economic growth. Knack and Keefer (1995) was a pioneering work. Four important institutional variables were proposed by Knack and Keefer (1995): protection of property rights, rule of law, corruption and bureaucratic quality. Such data were compiled from International Country Risk Guide (ICRG) data, published by the U.S.-based Political Risk Services Group, and from Business Environment Risk Intelligence (BERI), based in Switzerland. The ICRG index includes protection of property rights (expropriation risk and repudiation of contracts by government), rule of law, corruption, and bureaucratic quality. The BERI index includes contract enforceability, nationalisation potential, bureaucratic delays and infrastructure quality. Knack and Keefer run a regression for 97 countries in the period 1974-89. The explanatory variables include institutional quality (ICRG or BERI), initial per capita GDP, initial human capital, average annual government consumption share/GDP, distortion index (absolute value of deviation of investment price level), the number of revolutions and coups per year and the number of political assassinations per year per million population in the period 197489. To avoid possible simultaneity between growth and institutional quality, the authors chose the initial value of the institutional indices rather than the average for the whole period. The earliest release of BERI was 1974 and that of ICRG 1982. The scale for BERI was from 0 to 4 and for ICRG from 0 to 10 (the higher the better). The findings indicated that the ICRG index was positive and highly significant across the specifications. The BERI index was positive and significant for most specifications. Mauro (1995) used a different dataset of institutions from Business International (later incorporated into the Economist Intelligence Unit). His institutional variables included corruption and bureaucratic efficiency (including corruption, efficiency of the judiciary system, and bureaucratic red tape). The data were collected for the period 1980-83. The dependent variable was average per capita GDP growth during 1960-85. The explanatory variables included initial per capita income in 1960, population growth, primary education in 1960 , government expenditure share, revolutions and coups, assassinations, political 
instability, two distortion indices (absolute value of deviation of investment price level and its standard deviation), dummies for regions, and Mauro's corruption index or bureaucratic efficiency index. The finding was that both low bureaucratic efficiency and high corruption exerted strong and negative effects on growth. Their effects were statistically significant. Other significant studies include Sachs and Warner (1997a, 1997b), Barro (1998), Brunetti et al. (1997), Kaufman et al. (1999b), Aron (2000). Their findings in general indicate positive effects of institutional quality on economic growth.

This paper is aimed to explore a different but relevant relationship, i.e., the question is how institutions affect on efficiency of investment. The efficiency of investment is defined as the incremental capital-output ratio (ICOR). The ICOR measures the additional amount of capital required to produce an additional unit of output. The reciprocal of ICOR measures the productivity of additional capital (Gillis et al. 1992). The efficiency of investment is vital to growth because the level of investment alone cannot fully explain growth performance across countries. It is noteworthy that some countries can achieve a fairly high investment rate, but only slow growth. For example, during the period 1961-85, Argentina, Jamaica and Zambia achieved an investment/GDP rate as high as that of Taiwan, Malaysia and Thailand, but could only achieve a growth rate less than a third of the latter group. The main hypothesis of this paper is that quality of institutions has positive effect on investment efficiency.

\section{Literature Review}

\subsection{Institutions}

It has been argued that mainstream economics often takes institutions for granted. As we know, the basis of a modern market economy is the operation of economic exchange and cooperation among individuals or groups in society. Without institutions, it is argued that no economic exchange or cooperation can take place. It is because 'one person cannot interact with another without some shared understanding about how the other will respond and some sanction if the other responds arbitrarily and contrary to agreement. Private individuals and businesses can only buy, sell, employ labour, invest and explore innovations if they can have some confidence that their expectations will be met' (Kasper and Streit 1998, p. 2). Without institutions, human action becomes very uncertain, and hence the existence of widespread cheating, shirking, opportunism, etc. Then the costs and risks of economic exchange and cooperation are so high that they become difficult to achieve. Institutions reduce uncertainty, and hence the costs and risks of economic exchange and cooperation by making human action more predictable. North $(1990,1994)$ says that institutions provide a structure to everyday life. As a result, the effectiveness of institutions in facilitating economic exchange and cooperation plays a major role in explaining economic performance across nations. Moreover, formal and informal institutions together define the incentive structure of societies and economies. The incentive structure guides resource allocation, and hence the efficiency of an economy.

Institutions as defined above are indeed very broad, including a wide variety of factors ranging from formal institutions to informal institutions such as culture, religion, ideology, etc. Therefore, until now there is no integrated variable that can capture all dimensions of institutions, which can be used for empirical crosscountry comparison. Knack and Keefer (1995) pioneered using four below indicators to capture institutional quality for cross-country empirical comparison. 


\section{Protection of property rights}

Among the institutions that are the main bases for a market economy to operate in general, and for entrepreneurs to function in particular, property rights are considered one of the most important. Indeed, North and Thomas (1973), North (1990) and Knack and Keefer (1995), just to name a few, have argued that private property rights were a factor behind the rise of Western capitalism. Without secured private property rights, a society finds it difficult to develop.

Property rights to an asset are defined in the literature as the exclusive rights to control, use, benefit from, hire out or transfer that asset (Kasper and Streit 1998). The asset can be tangible (physical) or intangible (such as intellectual property). Private property rights are those of individuals and private organisations. Property rights are stressed not merely from their stipulation in law but also from their actual implementation.

The establishment and security of property rights are considered to have some important implications for investment efficiency and economic growth.

First, an economic exchange is in fact the exchange of property rights. As a result, without proper security of property rights fewer transactions would take place. That would mean less specialisation, less division of labour, and less productivity growth. Rearranging resources (through market transactions) to their most productive uses cannot be possible if property rights are not clearly defined, secured and transferable. Transaction costs would be high and complex transactions would be restricted. Moreover, when property rights are not properly secured, the owner of an asset has to spend more resources to exclude others from using it. Higher exclusion costs lower the value of the property (Kasper and Streit 1998).

Second, less security of property rights results in less investment and less productive activities. When owners of assets cannot reap all the benefits from them, they are less motivated to invest and to exploit them in the most productive way.

Third, it is argued that in societies where all individuals hold legally protected property rights to their own labour and human capital, with rights to contract relatively freely, people will be more motivated to work, to learn and to accumulate expertise and therefore innovation and economic productivity will be increased.

Fourth, the structure of property rights has implications for resource allocation because it stipulates the incentive structure of society. In a society where property rights are unsecured, individuals and organisations often restrict themselves to activities that are 'secured' by the state. Most talents and productive resources of society find their way to rent-seeking activities and other non-productive activities rather than to productive activities.

\section{Rule of law}

An issue which is recognised as closely related to property rights is the rule of law. Knack and Keefer (1995, p. 225) define the rule of law as a variable reflecting the degree to which the citizens of a country are willing to accept the established institutions to make and implement laws and adjudicate disputes. Higher scores for this variable indicate sound political institutions, a strong court system, and provisions for an orderly succession of power. Lower scores mean a tradition of depending on physical force or illegal means to settle claims and that new leaders may be less likely to accept the obligations of the previous regime. By this definition, we see that the rule of law and security of property rights are closely associated with each other. In a country where the rule of law is low, we expect property rights to be less secured because laws do not exist or are not properly enforced, and there is a high risk of the 
government expropriating property or repudiating contracts.

\section{Corruption and bureaucratic quality}

The definition of corruption used by the World Bank and many scholars is the abuse of public office for private gains. Public office can relate to public position or public resources. Corruption has the following detrimental effects on investment efficiency and economic growth.

Corruption is a kind of arbitrary tax, thereby raising transaction costs and uncertainty for business activities (Gray and Kaufmann 1998; Wei 1997). Wei (1997, p.1) argues that 'corruption, unlike tax, is not transparent, not pre-announced, and carries a much poorer enforcement of an agreement between a briber and a bribee. In other words, corruption embeds arbitrariness and creates uncertainty.' Permits, licenses, red tape, delays... all increase transaction costs and uncertainty for productive activities.

Corruption tends to reduce government revenues (Elliott 1997, Gray and Kaufmann 1998) because tax evasion becomes widespread, but it tends to increase public expenditure in order to create opportunities for corruption. This creates fiscal problems (Tanzi 1998), reducing state investments in infrastructure which are important for economic growth. Corruption also reduces the quality of government services, and of infrastructure, education and health care, etc. (Elliott 1997).

Corruption leads to inefficient resource allocation (Bardhan 1997, Gray and Kaufmann 1998). In the public sector, corruption may shift public investments away from the most profitable projects to less profitable projects with better opportunities for corruption (Shleifer and Vishny 1993). In the private sector, Elliott (1997) argues that corruption favours those with close connections with public officials over those who may be the most productively efficient. Officials may refuse to deal with those whom they do not have close relationships with due to fear of exposure.

Corruption tends to worsen the allocation of talents in society by encouraging rent-seeking rather than entrepreneurship. Bardhan (1997) and Elliott (1997) argue that there are a number of reasons to believe there is an increasing return to rent-seeking, for example an increase in rent-seeking lowers the cost of further rent-seeking. Talents in society are allocated with a bias towards rent-seeking rather than towards entrepreneurship and other productive activities.

Corruption also tends to slow down the process of technological transfer and development through cumbersome, timeconsuming permits, licenses, customs procedures, etc. (Mauro 1995).

Corruption undermines rule of law and property rights, thereby reducing incentives to invest and to carry out productive activities (Gray and Kaufmann 1998, Mauro 1995, Tanzi 1998). For example, entrepreneurs may fear that some of the future proceeds of their investments may be claimed by corrupt officials in a large number of ways, hence reducing investments. With corruption, laws are often poorly enforced and public officials can arbitrarily impose additional 'regulations' on entrepreneurial activities.

Corruption exacerbates the problem of inequality and poverty. This in turn retards government legitimacy (Elliott 1997, Gray and Kaufmann 1998). As a result, this may lead to political instability and more disruption for government policies and the process of economic growth.

Overall, corruption reduces investment (Bardhan 1997, Gray and Kaufmann 1998, Mauro 1995, Shleifer and Vishny 1993, Tanzi 1998), including foreign investment (Gray and Kaufmann 1998; Wei 1998), and leads to more inefficiency 
of investment because resources are misallocated. As a consequence, less economic growth is achieved.

It is worth noting a line of argument that corruption may be a kind of 'grease' that lubricates the wheels of a rigid administration, helping economic activities rather than hampering them (see, for example, a survey of this line of argument in Bardhan 1997, Kaufmann and Wei 1999, Mauro 1995, Shleifer and Vishny 1993, Tanzi 1998). However, Gray and Kaufmann (1998) show evidence that this is not true. It is often thought that bribery is paid in order for businesses to have less bureaucracy to deal with and acquire more privileges for their operations. Evidence in the World Economic Forum's Global Competitiveness Survey 1997 showed that 'enterprises reporting a greater incidence of bribery also tend - even after taking firm and country characteristics into account - to spend a greater share of management time with bureaucrats and public officials negotiating licenses, permits, signatures, and taxes. And the evidence also suggests that the cost of capital for firms tends to be higher where bribery is more prevalent.' (p. 8). The same evidence was found in Kaufmann and Wei (1999). Moreover, corruption tends to create a vicious circle of corruption - increased counter-productive regulations and control - and further corruption. Tanzi (1998) argue that corruption may induce public officials to introduce more leg islation which creates new obstacles and more opportunities for them to engage in corrupt practices. Indeed, some regulations are intentionally created to extract bribes (Tanzi 1998, p. 582).

Another indicator of good governance is the quality of services provided by the government (bureaucratic quality). Although the quality of public services tends to be highly correlated with the level of corruption, 'clean' governments may not provide public services very efficiently, and there is a wide variation in the quality of public services provided by corrupt governments. Therefore, in addition to the variable of corruption, this variable is necessary for cross-country study to measure 'the efficiency of the government.' The relationship between the quality of government services and economic growth is expected to be positive. The higher the quality of government services, the lower the transaction costs and the less uncertainty that entrepreneurs face. This should mean higher economic growth.

\subsection{Investment Efficiency}

The efficiency of investment is defined as the incremental capital-output ratio (ICOR). The ICOR measures the additional amount of capital required to produce an additional unit of output. The reciprocal of ICOR measures theproductivity of additional capital (Gillis et al. 1992). With the above definition, when we think about efficiency of investment, we are not thinking only of profits, but generally about the new output (value added) that investment generates. If we can generate more output with less investment or with the same investment rate, we can say that efficiency of investment is higher. In the end, what we are interested in is the relative economic performance of nations. If a nation can produce more output than other countries with less investment or with the same investment rate, then efficiency of investment is higher there than in other countries. This performance will show up in a lower ICOR. Thus, our empirical analysis is aimed at explaining the differences in the ICOR across countries.

High capital accumulation is necessary but not sufficient for growth. Efficiency of capital accumulation is crucial. To be efficient, the process of accumulation must be associated with intensive efforts to imitate, learn and innovate which link accumulation to effective assimilation. This is because the essential feature of catchingup in developing countries is mastering advanced technologies and practices 
from developed countries. This process requires physical investment that embodies technical progress and entrepreneurship that can assimilate advanced technologies, turning them into efficient and competitive products. In this sense, countries with the same investment rate can produce quite different growth rates, depending on the effectiveness of assimilation.

\subsection{Institutions on Investment Efficiency}

It is obvious from the previous discussion that innovation, including imitative innovation, is key to investment efficiency. Institutions are akey determinant of innovation, and thus investment efficiency. Remarkable historical studies (North and Thomas 1973, Mokyr 1990, Rosenberg and Birdzell 1986) showed an overwhelmingly important role for institutions in innovation. Historical evidence indicated that China could not turn its early advantage of technologies into sustained economic growth because its economic, social and political environment did not provide a favourable incentive structure for innovators. North and Thomas (1973) argued that efficient economic organisation was key to the growth and rise of the West. It is efficient in the sense that the system of property rights and institutional arrangements give individuals incentives to innovate and conversely inhibit rent-seeking activities that reduce individual incentives. Economic progress was the outcome of raising the private rate of return on developing new techniques and applying them to the production process.

Rosenberg (2003) maintains that the principal role of institutions on economic growth is that they help reduce uncertainties associated with innovations. He argues that one of the most important features of technological innovations is a high level of risks and uncertainty associated with the innovation process. Therefore, the success of economic development lies in the ability to create legal and political institutions that reduce the intolerable risks and uncertainties that are associated with the introduction of new innovation and technology.

In general, institutions affect investment efficiency because they determine transaction costs, and the incentive structure provided by institutions strongly affects resource allocation to productive or rent-seeking activities. Institutions provide structure for human interaction, without which entrepreneurship through imitation, learning and innovation cannot take place.

North (1990) and Niehans (1998) argued that, with transaction costs, both the volume of transactions and efficiency decline. With transaction costs, distance and complex transactions may not be possible because the costs and uncertainty that accompany them may be prohibitively high. In an economy with higher transaction costs, efficiency is relatively lower because economic exchange is more limited, and there are fewer economies of scale and less specialisation. More resources and effort are required to produce the same amount of output. Rearranging resources (through market transactions) to their most productive uses cannot be possible if property rights are not clearly defined, secured and transferable. In addition, Kasper and Streit (1998) argued that when property rights are not properly secured, the owner of an asset has to spend more resources to exclude others from using it. Higher exclusion costs lower the value of the property.

Corruption can generate significant costs for private businesses. It is a kind of arbitrary tax and leads to inefficient investment (Bardhan 1997, Gray and Kaufmann 1998). In the public sector, corruption may shift public investments away from the highest profitable projects to lower profitable projects with better opportunities for corruption (Shleifer and Vishny 1993). In the private sector, 
Elliott (1997) argues that corruption favours those with close connections with public officials over those who may be the most productively efficient. Officials may refuse to deal with those they do not have close relationships with because of fear of exposure. Corruption tends to slow down the process of technological transfer by cumbersome, time-consuming permits, licenses, customs procedures, etc. (Mauro 1995).

De Soto $(1989,2000)$ provided convincing evidence of the costs of corruption on economic activities. In order to measure how costly it is to do business, he and his research team opened a small garment workshop on the outskirts of Lima, Peru in 1983. Their goal was to create a new and perfectly legal business. The team spent time filling in forms, standing in queues, taking bus trips to government agencies, etc. In the process of applying for the project, ten bribes were asked, but only two were paid. The entire process took 289 days. The cost of legal registration was $\$ 1,231$ - thirty-one times the monthly minimum wage. In another case study, it took six years and eleven months, and 207 bureaucratic steps in 52 government offices to obtain legal authorisation to build a house on state-owned land. Opening a small store legally meant complying with administrative procedures with three different government departments, taking 43 days and costing $\$ 590$ - 15 times the monthly minimum wage. The procedure to obtain recognition for a minibus or a taxi route took about 26 months of rep tape. The lack or ineffectiveness of a formal property system drives many assets and businesses related to them to operate informally. However, the costs of operating informally are also very high. De Soto (2000) estimates that the cost of operating a business informally in Peru includes paying from 10 to 15 percent of its annual income in bribes and commissions to authorities.

Another important way in which institutions contribute to efficiency is through the incentive structure that guides the allocation of talent. North (1990) argued that the kinds of knowledge, skills and learning that individuals in society acquire depend on the structure of payoffs embedded in the institutional structure. A particular institutional structure is associated with a particular incentive structure that may or may not be favourable to entrepreneurship and efficiency. According to Baumol (1990, 1993), entrepreneurs have profit motives, so they tend to invest their talent where they can get the highest returns, irrespective of productive or rent-seeking activities. As such, efficiency and growth would be reduced with an institutional structure that favoured rent-seeking rather than entrepreneurship. "The allocation of entrepreneurship between productive and unproductive activities, though by no means the only pertinent influence, can have a profound effect on the innovativeness of the economy and the degree of dissemination of its technological discoveries.' (Baumol 1993, p. 40).

In summary, institutions may be vital to the efficiency of investment. Innovation is the social process by which a new technology, idea or practice is put into use and is sensitive to various institutional factors. The principal role of institutions in economic growth is to help reduce the uncertainties associated with innovations. Economic progress was the outcome of raising the private rate of return on developing new techniques and applying them to the production process. Institutions provide a structure for human interaction that helps reduce uncertainties and opportunistic behaviour, thus facilitating impersonal exchange, specialisation and the economies of scale. The quality of institutions determines transaction costs. The incentive structure provided by institutions strongly affects the allocation of resources to productive or rent-seeking activities. Corruption increases the costs of doing business and imposes efficiency loss. 


\subsection{Empirical Model}

Having identified the possible effects of institutions on investment efficiency, we now have to test them empirically. The specification for the investment efficiency function takes the form of a regression equation as follows:

$$
Y=a_{0}+a_{1} X_{1}+a_{2} X_{2}+\ldots+a_{n} X_{n}+\varepsilon
$$

Where:

Y: Dependent variable

$\mathrm{X}_{1}, \ldots, \mathrm{X}_{\mathrm{n}}$ : Independent variables

$a_{0}, \ldots, a_{n}:$ coefficients

$\varepsilon$ : error term

The dependent variable is ICOR, measuring investment efficiency. The independent variables include quality of institutions. Besides the variable of institutions, we also include control variables as follows:

\section{Export Growth and Trade Openness}

It is argued that export expansion has a considerable effect on efficiency. The resource allocation effect of export has been predicted by comparative advantage trade theories. With the expansion of the export sector, there will be resource shifts between the export and non-export sector. These shifts take place in order to take the best advantages of export opportunities. The efficiency of resource allocation is reinforced by the effects of competition through international markets as argued by Balassa (1989), Milner (1990) and Sundrum (1994). In addition, a developing country often needs large amounts of foreign exchange to finance imports of technologies and inputs. Without sustained export growth, the country will lack sufficient foreign exchanges to finance these essential imports, which are critical for the effective assimilation of advanced foreign technologies, and will hence suffer reduced efficiency. Export growth speeds up the process of technological assimilation and innovation.
The effect of trade openness on investment efficiency is less clear. On the one hand, traditional trade theories emphasise gains when two countries trade with each other. The competition from imports applies pressure on domestic firms to be efficient. On the other hand, 'infant industry' argument argue that some initial protection may be justified to get dynamic gains. Initial protection is needed to support infant domestic industries, giving them the time and opportunity to learn, imitate and innovate so they can be internationally competitive later on.

\section{Financial development}

The availability of finance can be important to the efficiency of investment because lack of finance can prohibit good projects from being implemented. The role of financial development on the efficiency of investment has been emphasised from the viewpoint of its positive effects on the allocation of resources (Kitchen 1986; Levine 1997). Another possible channel of influence is that the availability of credit makes it easier for Schumpeter's innovations to be readily carried out. According to Kitchen (1986) and Levine (1997), financial institutions are better at evaluating and selecting entrepreneurs who are undertaking investment projects than individual savers, thereby increasing the efficiency of investment. Financial institutions are also in a much stronger position to punish bad borrowers than individual savers. Furthermore, by punishing managers who do not perform well in the form of withdrawing loans, cutting future loans or liquidating firms' assets, financial institutions exert more discipline on firms than individual lenders. Levine (1997) argued that, while savers generally do not like risk, high-return projects tend to be riskier than low-return projects. Thus, by pooling financial resources and risks together, financial institutions induce a portfolio shift toward projects with higher expected returns. 


\section{Public sector}

There are two main variables to capture the effect of the public sector on the efficiency of investment: public investment and public consumption. However, the general effect of public investment on the ICOR is ambiguous. On the one hand, it is argued that public investment is often influenced by political interests rather than by entrepreneurship, thus increasing inefficiency. If the quality of governance is low, public investment tends to be associated with high corruption and thus, inefficiency of investment. On the other hand, public investment tends to be focused on infrastructure or public utilities that are very capital-intensive and have long gestation periods, thus incurring a higher ICOR. If we take the linkage of public-private investment into account, we see that public investment in infrastructure and public goods is important to private activities, reducing the costs of private business and thus increasing efficiency. Good infrastructure appears to raise the return on private economic activities. Barro (1998) emphasised that large public consumption may have a negative effect on efficiency and growth. His argument is that public consumption is spent on nonproductive purposes that do not improve productivity.

\section{Human capital}

Education is considered the most important element of human capital. However, according to Nafziger (1990) the relationship between education and efficiency is not straightforward. On the one hand, higher education may have positive effects on entrepreneurship. Highereducated people can be more innovative, find it easier to acquire new ideas and methods, may make sounder business decisions, etc. On the other hand, Nafziger argues that the time and money spent on formal education may reduce the time and resources for entrepreneurial activities. Education also may limit entrepreneurship by giving people other occupational choices. Also, higher- educated people may be highly risk-averse, which will reduce their entrepreneurial spirit. Explaining where 'all the education has gone' in many developing countries, Pritchett (1999, p. 24) noted several reasons why education did not have a better effect on growth: i) years of education went into poor quality schooling that created little or no educational capital; ii) the supply of educational capital outstripped demand so that education had nowhere to go and the returns on schooling declined rapidly; and iii) that newly created educational capital went into piracy: privately remunerative, but socially unproductive activities.

\section{Initial per capita income}

The initial level of per capita income often appears on the explanatory list in growth regressions implied by Neoclassical growth theories of diminishing returns to capital. Thus, poor countries are supposed to have lower ICORs.

\section{Data and Estimation Results}

\subsection{Data}

The sample used for regression consists of 43 developing countries with available data, averaged over the period 1970-2000. The dependent and explanatory variables of the regression equation are as follows:

\section{The dependent variable}

ICOR (Incremental Capital-Output ratio): calculated as the ratio of the average investment rate divided by the average GDP growth rate, measuring investment efficiency. The lower the ICOR, the higher the efficiency of investment. Average, 19702000. Source: Author's calculations from World Development Indicators (WDI), 2003 published by the World Bank.

\section{The independent variables}

Ln of Initial GDP per capita (1970, constant USD 1995), source: WDI 2003.

Average years of schooling of total population over 15 years old in 1970, proxied for human capital. To avoid possible 
endogeneity between education and growth, we used the initial value (1970) instead of the average value. Source: Barro-Lee dataset 2000 .

Export growth rate (\%), average for the period 1970-2000. Source: calculated from WDI 2003. In addition, we also test with Trade/GDP ratio (\%) and the openness index (1965-90) constructed by Sachs and Warner. Trade/GDP ratio (\%) is the average for the period 1970-2000. Source: calculated from WDI 2003.

Public consumption: general government final consumption expenditure (formerly general government consumption), including all government current expenditures for purchases of goods and services (including compensation of employees). It also includes most expenditures on national defence and security, but excludes government military expenditures that are part of government capital formation. The variable is the general government final consumption expenditure/ GDP ratio (\%), averaged for the period 197098. Source: calculated from WDI 2003.

Institutions (Institutional quality): Average for four indicators: protection of property rights (government repudiation of contracts, risk of expropriation), corruption, rule of law, bureaucratic quality. 1984 was chosen as the earliest year. The higher the index, the better the quality of institutions (scale from 0 to 10). The data are from the International Country Risk Guide compiled by Knack and Keefer (1995).

\subsection{Estimation Results}

Table 1 reports the regression results. The first regression (I) includes quality of institutions, export growth, financial development, public consumption, and initial per capita income. In the second and third regressions (II) \& (III), we replace export growth by trade/GDP share and Sachs-Warner openness index, respectively. In the fourth regression (IV), the variable on education - initial years of schooling - is included. The results indicate that quality of institutions and export growth have a strong positive and significant effect on efficiency of investment (negative effect on the ICOR) while initial per capita GDP and public consumption have a significant negative effect on efficiency of investment. Education, financial development, trade and openness do not have a significant effect on efficiency of investment.

The effect of the quality of institutions on investment efficiency is statistically significant and positive as expected. The magnitude of the effect seems substantial. A one point increase in the index of quality of institutions is associated with a 1.0 to 1.8 point decrease in the ICOR. For example, the difference of the index of institutional quality between Malaysia (7.5 points) and Peru (3.3 points) is 4.2 points, which makes Peru's ICOR higher by 4.2. to 7.6 points compared with Malaysia. The ICOR of Malaysia is just 4.2 while that of Peru is 8.3 , which implies that, in order to achieve the same growth rate, the investment rate in Peru should be nearly twice higher than that in Malaysia.

Table 1

Regression results - Dependent variable: ICOR (Developing countries, 1970-2000)

\begin{tabular}{lcccc}
\hline Explanatory variable: & $(\mathbf{I})$ & $(\mathbf{I I})$ & (III) & (IV) \\
\hline Constant & -6.850 & -10.108 & -10.180 & -5.637 \\
& $(-1.35)$ & $(-1.97)$ & $(-1.98)$ & $(-1.38)$ \\
Log of initial per capita GDP & $2.111^{* * *}$ & $2.188^{* * *}$ & $2.164 * * *$ & $1.468^{* *}$ \\
& $(3.09)$ & $(2.91)$ & $(3.09)$ & $(2.12)$ \\
M3/GDP ratio (Initial) & -0.026 & -0.017 & -0.019 & 0.029 \\
Public consumption/GDP ratio & $(-0.38)$ & $(-0.23)$ & $(-0.27)$ & $(0.89)$ \\
& $0.606 * *$ & $0.647 * *$ & $0.787 * * *$ & $0.473 * * *$ \\
& $(2.06)$ & $(2.05)$ & $(2.79)$ & $(2.83)$
\end{tabular}




\begin{tabular}{lrrrr}
\hline Export growth rate & $-0.422^{* *}$ & & & $-0.450^{* * *}$ \\
Trade/GDP ratio & $(-2.03)$ & & & $(-3.32)$ \\
Sachs-Warner openness index & & 0.027 & & \\
Years of schooling (initial) & & $(0.87)$ & 2.303 & $(1.05)$ \\
Quality of institutions & & & & 0.595 \\
& $-1.240^{* *}$ & $-1.698^{* * *}$ & $-1.810^{* * *}$ & $-1.027^{* *}$ \\
& $(-2.09)$ & $(-3.15)$ & $(-2.97)$ & $(-2.35)$ \\
\hline Number of observations & 43 & 43 & 43 & 37 \\
\hline $\mathrm{R}^{2}$ & 0.5064 & 0.4730 & 0.4720 & 0.6247 \\
\hline
\end{tabular}

Source: Author's estimation.

Notes: Heteroscedasticity may be existent in cross-country data, so the standard errors for the coefficients are based on White's (1980) correction method. Numbers in parentheses are heteroscedasticconsistent t-statistics. (***) means significant at 1\% level, (**) at 5\% level, (*) at $10 \%$ level. We also tried the tests with inflation, public investment (as \% of GDP) and public capital (as \% of total public expenditure), terms of trade, and debt service ratio by adding them as explanatory variables in the above regressions, but they are statistically insignificant.

Export growth also has a significant and positive effect on efficiency of investment, as expected. One percentage point increase in the rate of export growth is associated with over a 0.4 point decrease in the ICOR. For example, the difference in export growth between South Korea (16\%) and Algeria (3\%) decreases South Korea's ICOR by over 5.0 points compared with Algeria. The ICOR of South Korea is 4.1 while that of Algeria is 8.4, which implies that, in order to achieve the same growth rate, the investment rate in Algeria should be more than twice as high as that in South Korea.

Nevertheless, the trade/GDP share and openness index are not statistically significant. This implies that the positive effects of openness cannot outweigh its negative effects on efficiency. This is quite possible, given the above argument about the mixed effects of trade on efficiency of investment.

Public consumption has a negative and significant effect on investment efficiency. A ten percentage point rise in the public consumption/GDP share tends to associate with a 4.7 to 7.9 point increase in the ICOR. As such, if governments save and spend efficiently, ICOR improves, but if they do not, ICOR worsens.

Average years of schooling, used as proxy for education, do not have a significant effect on the efficiency of investment. This result is unexpected given our emphasis on the role of human capital. But the empirical fact in many studies is that education is not closely associated with growth performance. Cross-country growth empirical studies have not shown a strong and consistent effect of education on growth. However, it should be noted that the data of average years of schooling cannot include training (i.e., out of formal school), learning-bydoing and experience which the concept of human capital encompasses. It also ignores the quality dimensions of schooling, such as input of teachers, substance of teaching, etc. Due to these reasons, average years of schooling may be a poor indicator for international comparison of human capital even though it is the best proxy available for this purpose so far.

Initial financial development does not have a significant effect on the efficiency of investment either. Initial per capita GDP shows a positive and significant relationship with the ICOR. This confirms the hypothesis of diminishing returns to capital.

\section{Conclusions}

This paper reviews the relationship between institutions and investment efficiency. Theoretically, quality of institutions can have significant effects on investment efficiency, thus economic 
growth. There are many empirical studies on the relationship between institutions and economic growth, but it is hard to find a study on the relationship between institutions and investment efficiency. This paper is an endeavour to fill in this gap. The main conclusion from this study is that the quality of institutions has strong positive effect on investment efficiency. Statistically, a one point increase in the index of quality of institutions is associated with a 1.0 to 1.8 point decrease in the ICOR. The implication is that developing countries must improve the quality of institutions to achieve better investment efficiency and higher economic growth. The principal components of institutions which should be focused on include protection of property rights, rule of law, to reduce corruption and to improve bureaucratic quality.

\section{References}

Balassa, B. (1989), Comparative Advantage, Trade Policy and Economic Development, New York: Harvester Wheatsheaf.

Bardhan, P. (1997), 'Corruption and Development: A Review of Issues', Journal of Economic Literature, Vol. XXXV, September, pp. 1320-46.

Barro, R.J.(1998),DeterminantsofEconomic Growth, Cambridge, Massachusetts and London: MIT Press.

Baumol, W. J. (1968), 'Entrepreneurship in Economic Theory', American Economic Review, Vol. 58, pp. 64-71.

Baumol, W. J. (1990), 'Entrepreneurship: Productive, Unproductive, and Destructive', Journal of Political Economy, Vol. 98, October, pp. 893-921.

Baumol, W. J. (1993), Entrepreneurship, Management, and the Structure of Payoffs, Cambridge, Massachusetts and London: the MIT Press.

Brunetti, A., Kisunko, G., and Weder, B. (1997), 'Institutional Obstacles for
Doing Business: Data Description and Methodology of a Worldwide Private Sector Survey', World Bank Policy Research Working Paper, No. 1759, April.

Brunetti, A., Kisunko, G., and Weder, B. (1998), 'Credibility of Rules and Economic Growth: Evidence from a Worldwide Survey of the Private Sector', World BankEconomic Review, Vol. 12, No. 3: 353-84.

De Soto, H. (1989), The Other Path: The Invisible Revolution in the Third World, New York: Harper \& Row, Publishers.

De Soto, H. (2000), The Mystery of Capital: Why Capitalism Triumphs in the West and Fails Everywhere Else, New York: Basic Books.

Elliott, K. A. (1997), Corruption and the Global Economy, Washington, DC: Institute for International Economics.

Gillis, M., Perkins, D. H., Roemer, M. and Snodgrass, D. (1992), Economics of Development, New York and London: W.W. Norton \& Company.

Gray, C. W., Kaufmann, D. (1998), 'Corruption and Development', Finance \& Development, March.

Kasper, W. and Streit, M. E. (1998), Institutional Economics: Social Order and Public Policy, Cheltenham, UK: Edward Elgar.

Kaufmann, D., Kraay, A., and ZoidoLobaton, P. (1999a). 'Aggregating Governance Indicators'. World Bank Policy Research Department Working Paper No. 2195, Washington, D.C.: World Bank.

Kaufmann, D., Kraay, A., and ZoidoLobaton, P. (1999b). 'Governance Matters'. World Bank Policy Research Department Working Paper No. 2196, Washington, D.C.: World Bank. 
Kitchen, R. L. (1986), Finance for the Developing Countries, Chichester and New York: John Wiley \& Sons.

Knack, S. and Keefer, P. (1995), 'Institutions and Economic Performance: CrossCountry Tests Using Alternative Institutional Measures', Economics and Politics, Vol. 7, No. 3, November, pp. 207-27.

Levine, R. (1997), 'Financial Development and Economic Growth: Views and Agenda', Journal of Economic Literature, Vol. XXXV, June, pp. 688-726.

Mauro, P. (1995), 'Corruption and Growth', Quarterly Journal of Economics, August, Vol. 110, No. 3, pp. 681-713.

Milner, C. (1990), Export Promotion Strategies: Theory and Evidence from Developing Countries, New York: Harvester Wheatsheaf.

Mokyr, J. (1990), The Lever of Riches, New York: Oxford University Press.

Nafziger, E. W. (1990), The Economics of Developing Countries, SecondEdition, New Jersey: Prentice-Hall, Inc.

Niehans, J. (1998), 'Transaction Costs', in Eatwell, J., Milgate, M. and Newman, P. (eds.) (1998), The New Palgrave: A Dictionary of Economics, London: Macmillan.

North, D. C. (1990), Institutions, Institutional Change, and Economic Performance, Cambridge: Cambridge University Press.

North, D. C. (1994), 'Economic Performance through Time', American Economic Review, Vol. 84, No. 3, pp. 359-68.

North, D. C. (1997), 'The Contribution of the New Institutional Economics to an Understanding of the Transition Problem', WIDER Annual Lectures 1, Helsinki: WIDER.
North, D. C. and Thomas, R. (1973), The Rise of the Western World: A New Economic History, Cambridge: Cambridge University Press.

Pritchett, L. (1999), 'Where Has All the Education Gone?', Policy Research Department, World Bank, Working Paper No. 1581, Revised Copy.

Rosenberg, N. (2003), 'Property Rights and Economic Growth', Paper presented at the Riksdag Building in Stockholm for a seminar arranged jointly by the Ratio Institute and the Stockholm Chamber of Commerce, on 16 January.

Rosenberg, N. and Birdzell, L. E. (1986), How the West Grew Rich: the Economic Transition of the Industrial World, London: Tauris.

Sachs, J. D. and Warner, A. M. (1997a), 'Sources of Slow Growth in African Economies', Journal of African Economies, December, Volume 6, Number 3, pp. 335-376.

Sachs, J. D. and Warner, A. M. (1997b), 'Fundamental Sources of Long-Run Growth', AEAPapers and Proceedings, American Economic Review, Vol. 87, No. 2, pp. 184-8.

Shleifer, A. and Vishny, R. W. (1993), 'Corruption', National Bureau of Economic Research, Working Paper No. 4372, May, Cambridge, Massachusetts.

Sundrum, R. M. (1994), 'Exports and Economic Growth', in Meier, G. M. (ed.), From Classical Economics to Development Economics, Basingstoke, Hampshire and London: Macmillan Press Ltd.

Tanzi, V. (1998), 'Corruption around the World: Causes, Consequences, Scope, and Cures', IMF Staff Papers, Vol. 45, No. 4, December. 
Wei, Shang-Jin (1997), 'Why Is Corruption Wei, Shang-Jin (1999), 'Corruption in So Much More Taxing Than Tax? Arbitrariness Kills', National Bureau of Economic Research, Working Paper No. 6255, November, Cambridge, Massachusetts. Economic Development: Beneficial Grease, Minor Annoyance, or Major Obstacle?', World Bank Policy Research Working Paper, No. 2048, February. 